\title{
An Exploratory Study into the Accountancy Firms Chosen by Industrial Company IPOs in Australia from 1994 to 2004
}

\author{
Luisa Lombardi \\ Deakin University \\ E-Mail: luisa.lombardi@deakin.edu.au \\ William Dimovski \\ Deakin University \\ E-Mail:wd@deakin.edu.au
}

\begin{abstract}
This study is an exploration into the choice of independent accountants made by industrial initial public offering (IPO) companies in Australia between the years 1994 to 2004. The aim of this research is to determine which companies are more likely to use one of the Top 5 accountancy firms and in so doing we seek to offer some insight into understanding the likelihood of IPO companies adopting the services of the big accounting firms. Our findings show, as predicted, that the majority of industrial IPO companies, and particularly the larger companies, used one of the Top 5 accountancy firms as their independent accountant. However, unexpected was that certain industry types were less likely to hire a Top 5 accounting firm for their independent accounting services compared to other industry categories. Our studies also found that after the year 2000 a smaller percentage of companies used independent accountants than between 1994 and 1999. Many factors contribute to the selection of an independent accountant and this paper provides some understanding of identified factors and the influence that they have over the choice of independent accountants by industrial company IPOs.
\end{abstract}

Keywords: Initial Public Offering, Independent Accountant, Global Industry Classification Standard 


\section{INTRODUCTION}

Initial public offerings (IPOs) are issues of shares to the public for the first time with those companies subsequently seeking to be listed on a stock exchange. As such, these companies aspire to give information about them in a reassuring and positive manner so that the best vantage point can be attained to attract potential investors. The main avenue for communication of information to the public is the prospectus. Alongside information such as the history, future plans, management and financial position of the company, a prospectus includes a report from an independent accounting firm endorsing whether or not the financial information contained in the prospectus 'presents fairly' ${ }^{1}$. It can be hypothesised that the reputation of the accounting firm is an important consideration for IPOs because the public may be more likely to trust the opinions of, and the association with, the more reputable accountancy firms. As a result, IPOs may be more likely to use one of the Top 5 accounting firms as their independent accountant.

Accounting firms have been under much scrutiny following the implication of accountants in the demise of companies such as Enron, HIH, One-Tel, Harris Scarfe, and World Com. Prior to the demise of Arthur Andersen in 2002, the Top 5 firms accounting firms consisted of Arthur Andersen, Deloitte and Touché, Ernst and Young, KPMG and PricewaterhouseCoopers. It is these accounting firms that we refer to in this paper as the Top 5 accounting firms. The Top 5 accounting firms, prior to the Arthur Andersen collapse, were highly regarded and had a hold on being the most reputable of accountancy firms. Companies used the 'name' of the Top 5 accounting firm to provide credibility and assurance to their shareholders. Not only do IPOs face stringent regulatory compliance and reporting requirements, but they also strive to attract and reassure potential investors in their investment decision. The hiring of a Top 5 independent accountant is one way that an IPO can help ease the anxiety of potential investors.

This paper adopts some findings from earlier studies conducted exploring the connection between IPOs using one of the big accounting firms and the perceived credibility of the IPO (Beatty and Ritter, 1986; Rock, 1986; Beatty 1989; Menon and Williams, 1991; Holland and Horton, 1993; How et al., 1995; Hogan, 1997; Firth and Liau-Tan, 1998; Willenborg, 1999; Henry et al., 2002; Lee et al., 2003). This study expands from those earlier studies and explores industrial IPOs between 1994 and

\footnotetext{
${ }^{1}$ The independent accountant's report, also referred to as the investigating accountant's report, is ordinarily in the form of a review rather than an audit. The independent accountant usually uses the historical financial information and the pro-forma historical information included in the prospectus to perform the review and to compile the review statement.
} 
2004 to analyse what, when and why IPOs are more likely to use one of the Top 5 accounting firms as their independent accountant..

The remainder of this paper is as follows. Section 2 briefly discusses some related IPO accountancy firm literature. Section 3 is a report of the findings. Section 4 contains our conclusions.

\section{RELATED LITERATURE}

Beatty and Ritter (1986) explain that IPOs exhibit some uncertainty about their value before listing. As such, IPOs would be expected to reassure their potential investors that they are a sound and safe investment while also aiming to gain the best price possible for their shares. Beatty and Ritter (1986) also argue that underpricing, the difference between the closing market price on the first day of trading and the initial offering price, is directly related to uncertainty and is what IPO companies would want keep to a miminum.

How et al. (1995) explored the impact that the reputation of the investigating accountant, the underwriter and the expert has on underpricing for 340 industrial IPOs over the period of 1980 to 1990, found that "larger firms tend to hire higher reputation investigating accountants and experts", and continue on to state that "IPOs associated with high reputation investigating accountants and experts have lower ex ante uncertainty surrounding the aftermarket issue price” (p.101).

Firth and Liau-Tan (1998) purport that credibility of new share issues is linked to the choice of audit firm and further add that "high quality auditors are associated with higher IPO market valuations and they allow entrepreneurs to retain lower ownership stakes in the IPO while maintaining market valuation” (p.145). Beatty (1989) found that "hiring of a 'nationally known' audit firm is related to less underpricing of an initial public offering of equity securities” (p.708). Consistent with Beatty (1989) and Firth and Liau-Tan (1998), Rock (1986), Beatty and Ritter (1986), Holland and Horton (1993) and Hogan (1997) also found that the hiring of a reputable auditor helps to ease underpricing.

Menon and Williams (1991) contend that:

"the reputation of the auditor is particularly likely to affect the perceived credibility of financial statements when a firm makes its initial public offering (IPO) of stock, Companies making IPOs typically are little known to investors, who, in the absence of alternative sources of information, must place substantial reliance on management's reports. If financial statement users differentiate between levels of auditor credibility, this should be more readily detected in the IPO market than in 
markets for older, better-known companies" (p.314).

Lee et al. (2003) examined the Australian IPO market prior to 1990 and explored the relationship between IPOs using one of a Big 8 accounting firms and the extent of voluntarily disclosure information. Lee et al. (2003) found that "IPO firms choosing a Big 8 auditor are less likely (rather than more) risky than those selecting a Non-Big 8 auditor" (p.390). Lee et al. (2003) add "...the use of a high quality auditor likely compliments the signalling value of increased voluntary disclosure” (p.398).

Willenborg (1999) examined the demand for auditing in IPOs from the perspectives of the investors, the entrepreneurs and the auditors and argues that "the insurance demand for auditing is likely to dominate any information-based demand...even in the small-deal segment of the IPO market...” (p.237). Willenborg's findings are in contrast with our findings that the smaller IPOs $(<\$ 10$ million) are less likely to adopt the independent accounting services from one of the Top 5 accounting firms.

Although previous studies have traditionally explored the relationship between investor confidence and the choice of accounting firm made by IPOs for auditing services, they do provide a good basis for understanding the relationship between accounting firm reputation, the factors that may influence reputation and the choice of accounting firms in general made by IPOs. Previous studies have consistently found there to be a positive relationship between the choice of accounting firm and increased consumer confidence. This paper draws on prior related work and extends it to analysing the relationship between the choice of independent accountant and the size, industry type and year of listing of industrial IPOs between 1994 and 2004.

\section{DATA AND FINDINGS}

The analysis conducted is based upon data collected from the Connect 4 Prospectuses database. Accountancy firm and the total revenue turnover data came from the prospectuses of five hundred and seventy-four Australian industrial companies for the years 1994 to 2004. As shown in Table 1, the majority of IPO companies used an accounting firm from the Top 5 accounting firms (61\%) for their independent accounting needs. It appears the majority of IPOs believed they would benefit most by using a Top 5 accounting firm.

Table 2 reports the number of IPOs that used a Top 5 accounting firm according to size of the IPO. The data clearly shows that the smallest sized IPOs were less likely to use a Top 5 accounting firm (46\% of IPOs raising less than $\$ 10$ million) than the biggest sized IPOs ( $96 \%$ of IPOs raising more than $\$ 80$ million). To test whether the 
relationship between accounting firm choice (top 5 and other) and the size of the IPO capital raising is statistically significant we use a logit approach on the 574 observations since the dependent variable of accounting firm choice is binary. The model is as follows and the resultant coefficients and p-values (in brackets) are reported below.

$$
\begin{aligned}
\mathrm{L}: \operatorname{Pr}(\mathrm{A}=1)= & \beta_{0}+\beta_{1} \text { Totalmil }+\varepsilon \\
= & 0.011+0.018 \text { Totalmil } \\
& (0.918)(0.000)
\end{aligned}
$$

Table 1 Number of IPO companies from 1994 to 2004 that used one of the Top 5-accountancy firms for their independent accounting services.

\begin{tabular}{cccccc}
\hline IPO Companies & $\begin{array}{c}\text { No. of } \\
\text { companies } \\
\text { that used } \\
\text { one of the } \\
\text { Top 5 } 5 \text {-2004) } \\
\text { accounting } \\
\text { firms }\end{array}$ & $\begin{array}{c}\text { TO of } \\
\text { companies } \\
\text { that used } \\
\text { one of the } \\
\text { Top 5 } \\
\text { accounting } \\
\text { firms }\end{array}$ & $\begin{array}{c}\text { No. of } \\
\text { companies } \\
\text { that did } \\
\text { NOT use } \\
\text { one of the } \\
\text { Top 5 } \\
\text { accounting } \\
\text { firms }\end{array}$ & $\begin{array}{c}\text { \% of } \\
\text { companies } \\
\text { that did } \\
\text { NOT use } \\
\text { one of the } \\
\text { Top 5 } \\
\text { accounting } \\
\text { firms }\end{array}$ \\
\hline TOTALS & 574 & 352 & $61 \%$ & 222 & $39 \%$ \\
\hline
\end{tabular}

Where $\mathrm{L}: \operatorname{Pr}(\mathrm{A}=1)$ indicates a logit functional form and $\operatorname{Pr}(\mathrm{A}=1)$ indicates the equation is an estimate of the probability that a top 5 accounting firm $(=1)$ is used Totalmil = the size of the equity capital raising in millions of \$A.

The positive sign on the estimated coefficient for Totalmil and the highly significant p-value suggests larger IPOs were more likely to have used a higher profile accounting firm. This result is not surprising for two reasons. Firstly, the larger companies are endeavouring to attract a much larger amount of investors and capital and therefore aim to provide the greatest reassurance possible to potential investors by hiring one of the more reputable accounting firms. Second, the larger companies are more likely to afford the services of one of the Top 5 accounting firms.

Table 3 reports the number of IPO companies according to the universally recognised Global Industry Classification Standard (GICS) that used a Top 5 accounting firm. Interestingly, the two most prevalent users of the Top 5 accounting firms for independent accounting services were the utilities group, \#55, (78\%) and the telecommunication services group, \#50, (73\%). In part, this may be explained by the industry regulatory expectations on community services such as electricity, gas, water and telephone. The next most prevalent users of the Top 5 independent accountants 
were the industrials, \#20, (65\%). This group includes industries such as aerospace and defence, construction and engineering, airlines, road and rail, etcetera providing community and government services that are highly regulated and highly scrutinised by the public and therefore are more likely to need to use a reputable and high quality accounting firm.

Table 2 Number of IPO companies from 1994 to 2004, according to size, that used a Top 5-accountancy firm.

\begin{tabular}{lrrrrr}
\hline $\begin{array}{c}\text { Size of company } \\
\text { by turnover } \\
\$\end{array}$ & $\begin{array}{c}\text { Number of } \\
\text { companies } \\
\text { in this } \\
\text { range }\end{array}$ & $\begin{array}{c}\text { No. of } \\
\text { companies } \\
\text { that used a } \\
\text { Top 5 } \\
\text { accountancy } \\
\text { firm }\end{array}$ & $\begin{array}{c}\text { \% of } \\
\text { companies } \\
\text { that used a } \\
\text { Top 5 } \\
\text { accountancy } \\
\text { firm }\end{array}$ & $\begin{array}{c}\text { No. of } \\
\text { companies } \\
\text { that did } \\
\text { NOT use a } \\
\text { Top 5 } \\
\text { accountancy } \\
\text { firm }\end{array}$ & $\begin{array}{c}\text { \% of } \\
\text { companies } \\
\text { that did } \\
\text { NOT use a } \\
\text { Top 5 } \\
\text { accountancy } \\
\text { firm }\end{array}$ \\
\hline$<10$ million & 283 & 131 & $46 \%$ & 152 & $54 \%$ \\
\hline 10-29.99 million & 148 & 97 & $66 \%$ & 51 & $34 \%$ \\
\hline $30-79.99$ million & 76 & 60 & $79 \%$ & 16 & $21 \%$ \\
\hline$>80$ million & 67 & 64 & $96 \%$ & 3 & $4 \%$ \\
\hline TOTALS & 574 & 352 & $61 \%$ & 222 & $39 \%$ \\
\hline
\end{tabular}

Table 3 Number of IPO companies from 1994 to 2004 in each Global Industry Classification Standard (GICS) category that used a Top 5-accountancy firm

\begin{tabular}{|c|c|c|c|c|c|}
\hline $\begin{array}{l}\text { Companies as per } \\
\text { GICS category }\end{array}$ & $\begin{array}{c}\text { Number of } \\
\text { companies } \\
\text { in this } \\
\text { group }\end{array}$ & $\begin{array}{l}\text { No. of } \\
\text { companies } \\
\text { that used a } \\
\text { Top } 5 \\
\text { accountanc } \\
\text { y firm }\end{array}$ & $\begin{array}{c}\% \text { of } \\
\text { companies } \\
\text { that used a } \\
\text { Top } 5 \\
\text { accountancy } \\
\text { firm }\end{array}$ & $\begin{array}{l}\text { No. of } \\
\text { companies } \\
\text { that did } \\
\text { NOT use a } \\
\text { Top } 5 \\
\text { accountancy } \\
\text { firm } \\
\end{array}$ & $\begin{array}{c}\text { \% of } \\
\text { companies } \\
\text { that did } \\
\text { NOT use a } \\
\text { Top } 5 \\
\text { accountancy } \\
\text { firm } \\
\end{array}$ \\
\hline \# 15 Materials & 16 & 8 & $50 \%$ & 8 & $50 \%$ \\
\hline \# 20 Industrials & 181 & 117 & $65 \%$ & 64 & $35 \%$ \\
\hline $\begin{array}{l}\text { \# } 25 \text { Consumer } \\
\text { Discretionary }\end{array}$ & 107 & 67 & $63 \%$ & 40 & $37 \%$ \\
\hline \# 30 Consumer Staples & 33 & 16 & $48 \%$ & 17 & $52 \%$ \\
\hline \# 35 Health Care & 89 & 52 & $58 \%$ & 37 & $42 \%$ \\
\hline \# 40 Financials & 72 & 40 & $56 \%$ & 32 & $44 \%$ \\
\hline $\begin{array}{l}\text { \# } 45 \text { Information } \\
\text { Technology }\end{array}$ & 16 & 8 & $50 \%$ & 8 & $50 \%$ \\
\hline \# 50 Telecommunication & 51 & 37 & $73 \%$ & 14 & $27 \%$ \\
\hline \# 55 Utilities & 9 & 7 & $78 \%$ & 2 & $22 \%$ \\
\hline TOTALS & 574 & 352 & $61 \%$ & 222 & $39 \%$ \\
\hline
\end{tabular}


Table 3 reports that the remaining GICS category groups, except for the 'consumer staples' group, had at least half of their total use a Top 5 accounting firm. Upon further investigation we found that the 'consumer staples' group includes a large percentage of small turnover firms (55\% had a turnover of less than $\$ 10$ million). The 'consumer staples group' smaller percentage result (48\%) is more likely to be the result of the size of the firms in this group rather than the industry type.

Table 4 reports the number of IPO companies for each year between 1994 and 2004 that used a Top 5 accountancy firm. The findings reveal that from 1994 to 1999, at least $64 \%$ of IPOs used a Top 5 accounting firm but from the year 2000 until the year 2004 a decline in the use of the Top 5 accounting firms was evident showing that between $44 \%$ and $57 \%$ of IPOs used a Top 5 accounting firm. The year 2002 reports the lowest percentage of users of a Top 5 accounting firm at $44 \%$. Reasons for this drop in usage after the year 2000 may be many but we speculate that the main reasons for the decline in using one of the Top 5 accounting firms are:

1. the introduction of CLERP 9 and

2. the demise of Arthur Andersen. ${ }^{2}$

CLERP 9 is the ninth instalment of the Corporate Law Economic Reform Program (CLERP) $)^{3}$. CLERP was initiated in Australia in 1997 to allow for ongoing review and reform of regulation for Australia's corporations and businesses and CLERP 9 was initiated in response to the HIH collapse in 2001 to address the regulations governing audit and independence requirements. The Australian government engaged Professor Ian Ramsay ${ }^{4}$ to "undertake a comprehensive review of Australia's existing legislative and professional requirements on the independence of auditors" (The Department of the Treasury, 2002, p.41). In brief, CLERP 9 requires auditors to meet a standard of independence and auditors will be required to rotate after five years (Corporate Law Economic Reform Program (Audit Reform and Corporate Disclosure) Bill, 2003).

We suppose that the timing of the new legislation in 1999 is associated with the decrease in the number of IPOs that used one of the Top 5 from the year 2000, as reported in

Table 4. The introduction of CLERP 9, in particular, that requires a rotation of auditors and enforces auditor independence by restricting external auditors to provide non-audit services to their clients, has possibly led IPOs to adopting independent

\footnotetext{
${ }^{2}$ Arthur Andersen collapsed in 2002. Prior to its demise, Arthur Andersen was one of the Top 5 accounting firms.

${ }^{3}$ CLERP was enacted in 1999 and is known as the Corporate Law Economic Reform Program Act 1999.

${ }^{4}$ Professor Ramsay is in the Law school of Melbourne University, Melbourne, Victoria, Australia.
} 
accounting services from smaller to medium sized accounting firms to avoid any possible conflict of roles.

Interestingly, however, CLERP (as distinct to CLERP 9) tightens regulations and "there have been significant increases in the level of prospectus stop orders issued by the Australian Securities and Investments Commission (ASIC), the introduction of criminal penalties and on-the-spot fines imposed by ASIC” (Gallery et al., 2006, p.1). CLERP introduced a new chapter 6D to the Corporations Law that governs prospectus disclosures and associated penalties for false, misleading or omitted information. We, therefore, would have thought that the timing of the new CLERP legislation in 1999 would have been a greater drive for IPOs to adopt one of the Top 5 accounting firms. However, our findings reported a decline in the number of IPOs using a Top 5 accounting firm from the year 2000, and it therefore seems that the introduction of CLERP 9 that legislates auditor independence, was possibly a more influential factor for IPOs in their choice of an independent accountant.

Table 4 Number of IPO companies from 1994 to 2004, according to date of listing, that used a Top 5-accountancy firm.

\begin{tabular}{lccccc}
\hline $\begin{array}{c}\text { Year of IPO } \\
\text { Listing }\end{array}$ & $\begin{array}{c}\text { Number of } \\
\text { companies in } \\
\text { this range }\end{array}$ & $\begin{array}{c}\text { No. of } \\
\text { companies } \\
\text { that used a } \\
\text { Top 5 } \\
\text { accountancy } \\
\text { firm }\end{array}$ & $\begin{array}{c}\text { \% of } \\
\text { companies } \\
\text { that used a } \\
\text { Top 5 } \\
\text { accountancy } \\
\text { firm }\end{array}$ & $\begin{array}{c}\text { No. of } \\
\text { companies } \\
\text { that did NOT } \\
\text { use a Top 5 } \\
\text { accountancy } \\
\text { firm }\end{array}$ & $\begin{array}{c}\text { \% of } \\
\text { companies } \\
\text { that did NOT } \\
\text { use a Top 5 } \\
\text { accountancy } \\
\text { firm }\end{array}$ \\
\hline 1994 & 46 & 34 & $74 \%$ & 12 & $26 \%$ \\
\hline 1995 & 20 & 16 & $80 \%$ & 4 & $20 \%$ \\
\hline 1996 & 24 & 21 & $88 \%$ & 3 & $12 \%$ \\
\hline 1997 & 33 & 21 & $64 \%$ & 12 & $36 \%$ \\
\hline 1998 & 31 & 22 & $71 \%$ & 9 & $29 \%$ \\
\hline 2000 & 97 & 66 & $68 \%$ & 31 & $32 \%$ \\
\hline 2001 & 136 & 78 & $57 \%$ & 58 & $43 \%$ \\
\hline 2002 & 39 & 20 & $51 \%$ & 19 & $49 \%$ \\
\hline 2003 & 34 & 15 & $44 \%$ & 19 & $56 \%$ \\
\hline 2004 & 35 & 19 & $54 \%$ & 16 & $46 \%$ \\
\hline TOTALS & 79 & 40 & $51 \%$ & 39 & $49 \%$ \\
\hline
\end{tabular}


The second reason we suggest to explain the decline in IPOs using a Top 5 accounting firm after the year 2000 is the demise of Arthur Andersen. Prior to the news in 2001 that Arthur Andersen was involved with the Enron scandal, companies viewed that "an audit conducted by a small and relatively unknown firm, therefore, may not be worth much" (Thies, 2002, p.1). Thies (2002) adds, "the value of stock of the Big 5-audited public corporations seemed immune to such events" (p.1). The Enron scandal was closely timed to an Australian disaster that also saw Arthur Anderson implicated. The HIH insurance group was placed in provisional liquidation in early 2001 (The HIH Royal Commission, 2003) and companies were leaving Andersen's in large numbers. Thies (2002) said that "at least 143 corporate clients, out of 2,311, have left Andersen...” (p.1). It seems that those who left Andersen's elected to adopt the services of accounting firms that did not belong to the Top 5 group because the number of IPOs using a Top 5 accounting firm declined (see Table 4), particularly in 2002 where the smallest percentage for the 1994 to 2004 period was recorded. The trust and confidence in the Top 5 accounting firms had diminished and IPOs were looking elsewhere for independent accounting services. This second reason may be the more plausible.

\section{CONCLUSION}

Previous studies investigating factors influencing the choice of auditor made by IPOs have mainly come from the USA (Beatty and Ritter, 1986; Rock, 1986; Beatty, 1989; Menon and Williams, 1991 and Willenborg, 1999). These studies found a correlation between hiring a reputable auditor and consumer confidence by exploring various factors such as a) size of IPO company, b) ex-ante uncertainty, c) underpricing and d) credibility of the financial statements of the IPO. Our study contributes to the literature by exploring the relationship between the choice of independent accountants made by IPOs and the size of the company, the year of IPO listing and the category of industry type. In particular, this study investigates which Australian industrial IPOs between the years of 1994 to 2004 were more likely to have used one of the Top 5 accounting firms for their independent accounting needs.

The findings of this research confirm that most IPOs are likely to adopt one of the Top 5 accounting firms as their independent accountant. Not surprising the findings also confirmed that larger sized IPOs are more likely to adopt one of the Top 5 accounting firms as their independent accountant than smaller sized IPOs. However, more surprisingly, the findings revealed that a lower proportion of industrial IPOs used one of the Top 5 accounting firms from the year 2000 and that some industry 
types were more likely to use one of Top 5 accounting firms. The year 2002 reported the lowest number of IPOs that used a Top 5 accounting firm (44\%) and we speculate that this is related the demise of Arthur Andersen and the implication of Andersen in the downfall of some large companies. Not only was there a diminishment in consumer confidence in the large accounting firms, but Andersen clients needed to look elsewhere for their independent accountant. The industry type also seemed to be a factor in which accounting firm an IPO chose as their independent accountant. The utilities group, the telecommunication group and the industrials group of IPOs were the most prevalent users of one of the Top 5 accounting firms. We speculate that these findings are related to the industry regulatory expectations of these groups, and therefore IPOs in these groups are more likely to use a more reputed accounting firm. Whilst the USA studies have directed their research to the choice of audit firm chosen by IPOs, our research has focused on the choice of independent accountant made by Australian IPOs. The findings of our research for Australian IPOs does coincide in principle with the USA findings that reputation of the accounting firm does have a favourable impact on IPOs.

\section{REFERENCES}

Beatty, R. (1989). Auditor Reputation and the Pricing of Initial Public Offerings. The Accounting Review, 64(4), 693-709.

Beatty, R., and Ritter, J. (1986). Investment banking, reputation, and the underpricing of initial public offerings. Journal of Financial Economics, 15(1-2), 213-232.

Corporate Law Economic Reform Program (Audit Reform and Corporate Disclosure) Bill (2003). The Parliament of the Commonwealth of Australia. Retrieved January 20, 2007, from http://scaleplus.law.gov.au/html/ems/0/2003/0/ 2003120806.htm.

Firth, M., and Liau-Tan, C.K. (1998). Auditor Quality, Signalling, and the Valuation of Initial Public Offerings. Journal of Business Finance \& Accounting, 25(1-2), 145-165.

Gallery, G., Gallery, N., and Linus, A. (2006). The impact of recent regulatory change on the earnings forecasting behaviour of Australian Initial Public Offer firms, paper presented at the 2006 Accounting and Finance Association of Australia and

New Zealand Conference. Retrieved January 16, 2007, from http://www.accg.mq.edu.au/docs/pdf/seminar_papers/GGL_MacQuariepaper_ 20060807.pdf. 
Henry, D., Ahmed, K., and Riddell, A. (2002). The effect of IPO prospectus earnings forecast errors on shareholder returns. Journal of Corporate Communications, 4 , $1-27$.

Hogan, C. (1997). Costs and benefits of audit quality in the IPO market: A selfselection analysis. The Accounting Review, 72(3), 67-85.

Holland, K., and Horton, J. (1993). Initial public offerings in the unlisted securities market: The impact of professional advisers. Accounting and Business Research, 24(93), 19-32.

How, J., Izan, H., and Monroe, G. (1995). Differential information and the underpricing of initial public offerings: Australian evidence. Accounting and Finance, 35(1), 87-105.

Lee, P., Stokes, D., Taylor, S., and Walter, T. (2003). The association between audit quality, accounting disclosures and firm-specific risk: Evidence from initial public offerings. Journal of Accounting and Public Policy, 22, 377-400.

Menon, K., and Williams, D. (1991). Auditor Credibility and Initial Public Offerings. The Accounting Review, 66(2), 313-332.

Rock, K. (1986). Why New Issues are Underpriced. Journal of Financial Economics, $15,187-212$.

The Department of the Treasury, Australian Government (2002). CLERP Paper No. 9 Proposals for Reform - Corporate Disclosure, Part 4: Auditor Independence. Retrieved January 19, 2007, from http://www.treasury.gov.au/ documents/403/ HTML/docshell.asp?URL=Ch4.asp.

The HIH Royal Commission (2003). The failure of HIH: a critical assessment. Retrieved January 3, 2007, from http://www.hihroyalcom.gov.au/finalreport/ Front\%20Matter,\%20critical\%20assessment\%20and\%20summary.HTML\#_Toc 37086537.

Thies, C. (2002). The Demise of Arthur Andersen. Retrieved January 4, 2007, from http://www.gold-eagle.com/editorials_02/thies041502.html.

Willenborg, M. (1999). Empirical analysis of the economic demand for auditing in the initial public offerings market. Journal of Accounting Research, 37(1), 225-238. 
